\title{
The Roots of Philibert De l'Orme: Antiquity, Medieval Art, and Early Christian Architecture
}

\author{
Yves Pauwels
}

The French Renaissance is the daughter of antiquity and the Middle Ages. If the antique reference is the more spectacular one, its grounding in the medieval tradition was never excluded from sixteenth-century culture. In 1549, for a theorist of poetry as avant-garde as Joachim du Bellay, resorting to words of the 'vieil langaige françois' (old French language) could bring some originality to new poetry; even better, the use of certain medieval words gave 'great majesty' to the language:

Pour ce faire te faudrait voir tous ces vieux romans, et poètes français, ou tu trouveras un 'ajourner', pour faire jour [...], 'anuyter' pour faire nuit, 'assener', pour frapper où on visait, et proprement d'un coup de main, 'isnel' pour léger et mille autres bons mots, que nous avons perdus par notre négligence. Ne doute point que le modéré usage de tels vocables ne donne grande majesté tant au vers, comme à la prose: ainsi que font les reliques des Saints aux Croix, et autres sacrés joyaux dédiés aux temples.

In order to do this you would have to see all those old novels and French poets, where you will find 'ajourner' for to grow light [...], 'anuyter' for to grow dark, 'assener' for to hit one's target and literally with one's hand, 'isnel' for light and a thousand other good words that we have lost through negligence. Have no doubt that moderate usage of such words gives great majesty to verses as well as to prose, just as relics of saints do to crosses, and other sacred jewels intended for churches. ${ }^{1}$

Likewise, medieval art still retained value in architectural thought. Thus, if we can believe Étienne Pasquier (1529-1615), the author of the historic work Recherches de la France, which was first published in 1560, Jacques Androuet du Cerceau truly admired the Sainte-Chapelle in Paris:

1 Du Bellay Joachim, Deffence et illustration de la langue francoyse (Paris, Arnoul L'Angelier: 1549) chap. 6 , fol. e [=33 r-33 v].

(C) YVES PAUWELS, 2019 | DOI:10.1163/9789004378216_011

This is an open access chapter distributed under the terms of the prevailing CC-BY-NC-ND License 
La saincte Chappelle de Paris fut bastie par le Roy sainct Louys, d'une architecture admirable telle que nous pouvons voir. J'ay autrefois ouy dire à Maistre Jacques Androüet, dit du Cerceau, l'un des plus grands architectes qui se soient jamais trouvez en la France, qu'entre tous les bastiments faits à la moderne, il n'y en avoit point de plus hardy que celuy-là. Appellant bastiments à la moderne, comme une Eglise nostre Dame de Paris et autres tels, que sur nouveaux desseins furent introduits depuis le declin de l'Empire de Rome, n'ayans rien emprunté de toutes ces parades qui estoient auparavant, telles que celles dont depuis le sieur de Claigny voulut embellir le Louvre, sejour ordinaire de nos Roys dedans la ville de Paris. Or outre cette architecture je souhaitte que l'on considère les vitres de ce lieu, qui furent faites de telle façon, que les vitriers tiennent pour certain que l'usage et manufacture d'icelles en a esté depuis perdu.

The Sainte-Chapelle in Paris was constructed by King Saint Louis, of an admirable architecture, as we can see. I have heard it said by Master Jacques Androuet, called du Cerceau, one of the greatest architects ever found in France, that among all the buildings made in the modern style, not one was more bold than that one. We call buildings made in the modern style such as Notre Dame in Paris and and others like it, that on new designs were introduced since the decline of the Roman Empire, having borrowed nothing from all that ostentation which existed previously, such as those with which Lord de Clagny wanted to embellish the Louvre, the kings' usual residence inside the city of Paris. Now, in addition to this architecture I wish for the stained glass of this place to be considered; they were made in such a way that the glaziers are convinced that their use and manufacture have been lost since then. ${ }^{2}$

This appreciation was part of an Pasquier's overall approach to a promotion of French history dating back to the Gauls as described by Julius Caesar. 'Modern' architecture, in Pasquier's opinion, was well worth ancient ruins, when he wrote that sid ruins 'do not seem to me to be of fine construction'. ${ }^{3}$ From this point of view, Androuet du Cerceau's opinion is in no way surprising. The most well known of the architect's books, Les plus excellents bastiments de France

2 Pasquier, Étienne, Les recherches de la France d'Estienne Pasquier conseiller et avocat général du Roy (Paris, Laurent Sonnius: 1621) III, 38, 302.

3 Letter to M. de Foix, in Rome, quoted by Huppert G., "Naissance de l'histoire en France: les 'Recherches' d'Estienne Pasquier”, Annales. Economie, Sociétés, Civilisations 1 (1968) 69105,83 . 
(1576-1579), far from being limited to contemporary architecture, displays several examples of medieval structures: the châteaux of Vincennes, Creil, and Coucy being the most spectacular. In the volume he was planning to devote to Paris, ${ }^{4}$ Du Cerceau would probably have included the great Gothic sanctuaries. For Les plus excellents bastiments de France is not an informative work but a graphic epic - ordered by Catherine de Medici - to the glory of the French monarchy, which, in the same way that Ronsard sings of the exploits of the Valois dynasty in the Franciade, presents, as it were, the 'architectural exploits' of the kings and their vassals. ${ }^{5}$ From this historical point of view - insofar as the epic poem falls within the authority of history - it is normal that French architecture took root in the tradition of the great ancestors of the Middle Ages.

In France, religious architecture never abandoned ribbed vaults and triangular arched windows; in the château of Écouen (towards 1540-1550), the pavilion accommodating the chapel is easy to identify because of its Gothic windows. French architecture never gave up 'modern' origins. During the first period of the Renaissance, which blossomed at the end of the reign of Louis XII and during that of Francis I (1515-1547), French masons were mainly inspired by the art of Milan and by the Lombard style, but not yet by the classical ruins of ancient Rome. In this period, the coexistence of medieval and all'antica Italian forms was natural. The ornamental repertoire alone was transformed in order to change its shape, but not its nature or its function. In the copestones of the Saint-Gatien Cathedral in Tours (from 1508 to 1540), the north tower's gables were replaced in the south tower with pediments, and the pinnacles with ornate candelabra columns [Fig. 9.1]. Renaissance-style layouts were sometimes placed next to Gothic ornamentation, with no sort of transition from one to the other - see the façade of the collegiate church Saint-Jean-Baptiste des Roches-Tranchelion, in Touraine, built by the local lord Lancelot de la Touche starting in 1510 [Fig. 9.2]. These juxtapositions are also

4 Androuet du Cerceau, Jacques, Second Livre d'architecture (Paris, André Wechel: 1561) 2: 'attendant que Dieu me fasse la grâce de vous en présenter un autre, selon qu'il m'a été permis et ordonné par vos prédécesseurs Rois, tant des dessins et œuvres singulières de votre ville de Paris comme de vos palais et bâtiments Royaux, avec aucuns des plus somptueux qui se trouvent entre les autres particuliers de votre noble Royaume' ('Waiting for God to grant me the grace to present you with another, according to what your predecessor Kings have ordered me, with many drawings and remarkable works of your city of Paris, such as your palaces and Royal buildings, with some of the most sumptuous which are found among other mansions of your noble Kingdom'). This text (like the others quoted in this essay) is available on the website ARCHITECTURA, ed. F. Lemerle and Y. Pauwels (http://architectura.cesr.univ-tours .fr, retrieved 6 November 2017).

5 Pauwels Y., "Petits arrangements avec le réel. Jacques Androuet du Cerceau à Écouen", Revue de l'Art 178 (2012) 33-41. 


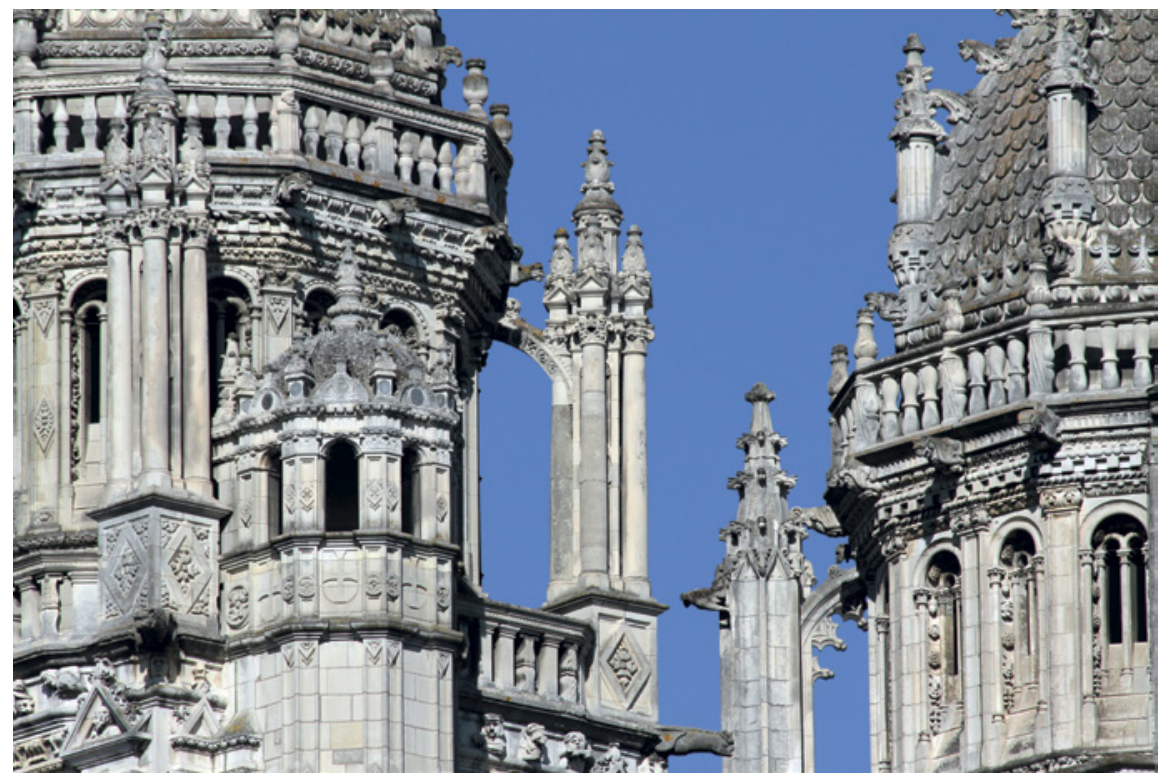

FIGURE 9.1 Detail of the copestones of the towers of the Saint-Gatien Cathedral at Tours

(1507-1547)

IMAGE (C) Y. PAUWELS

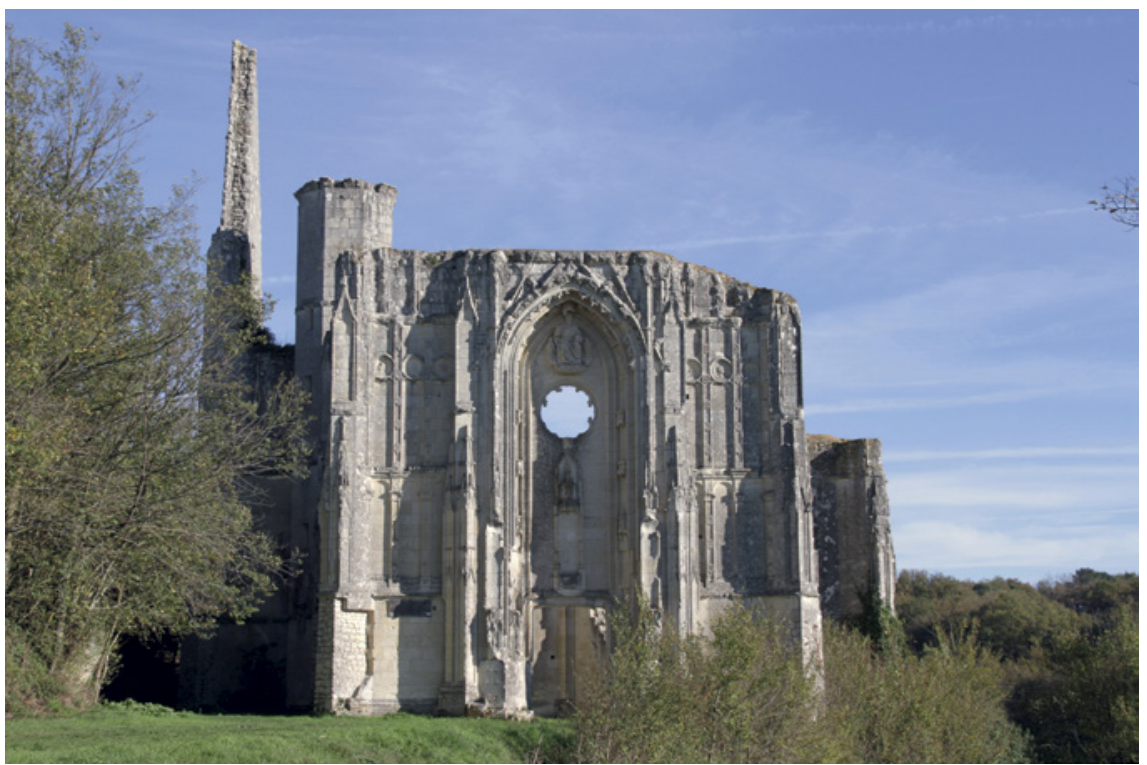

FIGURE 9.2 Collegiate Church St. John the Baptist at Les Roches-Tranchelion (ca. 1527) IMAGE (C) Y. PAUWELS 


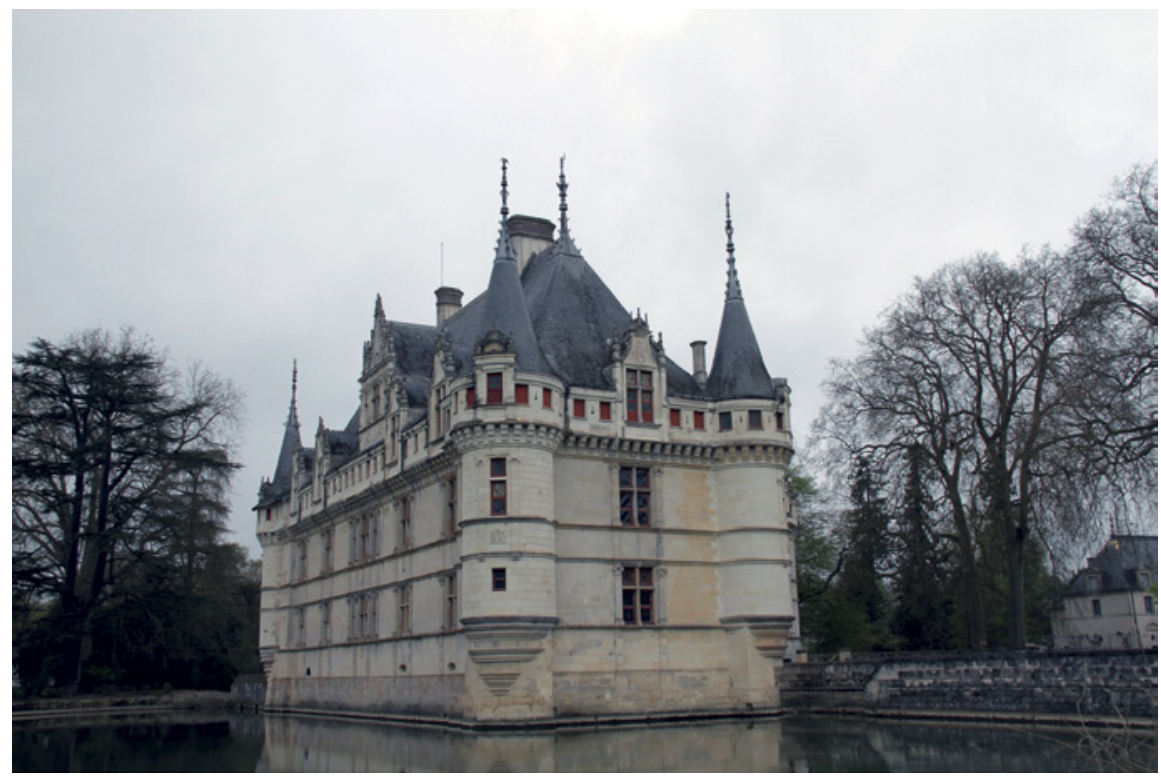

FIGURE 9.3 Château Azay-le-Rideau (1518-1527)

IMAGE (C) Y. PAUWELS

evident in more prestigious contexts, such as the château de Gaillon, where many flamboyant motifs are mixed in with the new repertoire borrowed from the Italian Renaissance.

The case of civil architecture is very significant. When, around 1515, rich financiers and recently ennobled persons, such as Thomas Bohier and Gilles Berthelot, built (in Chenonceau and Azay-le-Rideau, respectively) new castles strongly inspired in design by the Italian Renaissance and in decor by Lombard art, they wanted to keep traditional elements of the medieval 'châteauxforts' architecture for symbolic reasons. In doing so, they preserved a concrete testimony to the antiquity of the place, such as through a tower (the Tour de Marques in Chenonceau) or a dovecote (in Azay), which, as visual signs of nobility, testified to and legitimized their establishment in the fief they had just acquired. At the same time, since the natural function of the nobility in the Ancien Régime society was service in arms, it was important to keep, in addition to up-to-date all'antica ornaments, traditional forms recalling that the castle was also the house of a warrior. Thus, one can see in Azay-le-Rideau a covered walkway, battlements, and machicolations encircling the outside of the building [Fig. 9.3]. These devices are fakes: dormer windows interrupt the pseudo-covered walkway, and the machicolations are not operative. But they show the visitor that the castle is the home of a nobleman, and hence a warrior. 


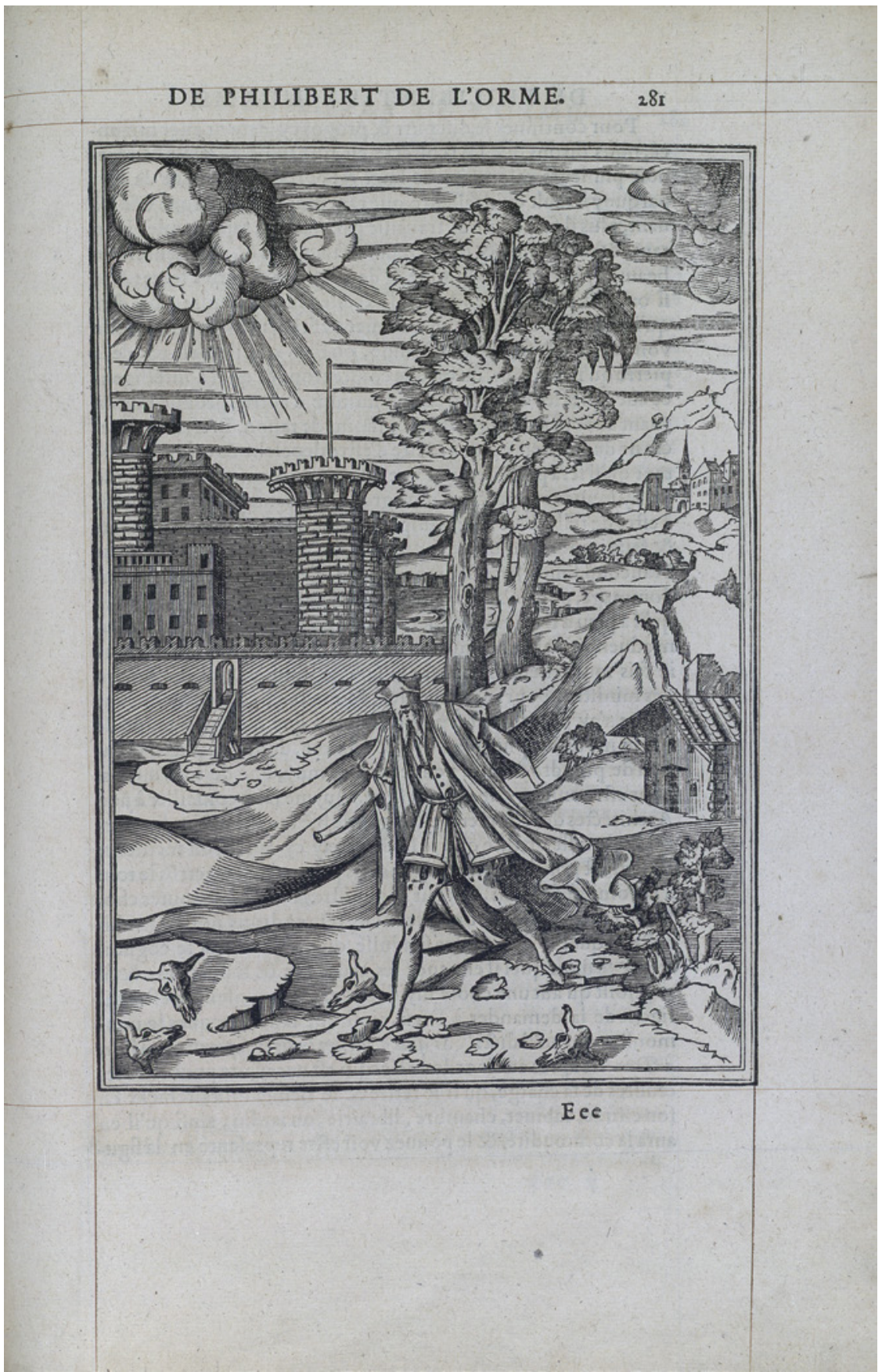

FIGURE 9.4 Allegory of the bad architect. From: Philibert De l'Orme, Le premier tome de l'architecture (Paris, Federic Morel: 1567), fol. 281 IMAGE @ ARCHITECTURA, CESR 
The assertion of these qualities was particularly urgent because these financiers were very recent arrivals to the aristocracy.

Things were more complex for the second or 'classical' Renaissance, from the 1540s, when, principally through Sebastiano Serlio's intervention, the Vitruvian lessons on the orders of architecture were adopted. There was no place there for Gothic obsolescence. But looking at it very closely, medieval roots continued to inspire new architects, such as Pierre Lescot and Jean Bullant, and Philibert De l'Orme (1514-1570) was at the forefront. De l'Orme is the most important and imaginative architect from this time. He worked for King Henry II, for the favorite Diane de Poitiers, and was surintendant des batiments du roi. After the king's death, he built the Palace of the Tuileries for Queen Mother Catherine de Medici, and wrote the first French complete treatise on architecture, the Premier tome de l'architecture, published in 1567. In his own way he was part of the movement toward reclaiming medieval heritage, a movement that was gaining importance. Specifically French, it participated in creating a national architecture, which was autonomous compared to the Italian designs, both antique and modern. Very significantly, if the symbolic representation of the 'good architect', which he offers at the end of the Premier tome de l'architecture ${ }^{6}$ is accompanied by good buildings in the antique style, the preceding representation of the 'bad architect' is not placed under ribbed vaults in churches with monstrous proportions [Fig. 9.4]. For Philibert, 'modern' architecture, which we call 'medieval', was not rejected a priori; it even provided a good number of elements which were destined to create a French architecture, free from an exclusive dependence on classical antiquity and Italian art, but with solid national and Christian roots.

\section{The Art of Vaulting}

The first reference, probably the most important one, is the mastery of the art of stonecutting, a heritage of Romanesque know-how. The most prestigious example is the twelfth-century spiral staircase located at the Saint-Gilles-duGard Abbey. De l'Orme was well acquainted with it; he visited it during a trip through Provence:

Telle voute ainsi rampante est appelée des ouvriers, la vis sainct Gilles: pour autant qu'il y en a une semblable au prieuré de sainct Gilles en Languedoc. J'ay veu en ma jeunesse que celui qui sçavoit la façon du traict

6 De l'Orme, Philibert, Le premier tome de l'architecture (Paris, Federic Morel: 1561), fol. $281 \mathrm{r}$. 
de ladicte vis sainct Gilles, et l'entendoit bien, il estoit fort estimé entre les ouvriers, et se disoit communement entre eux que celuy avoit grande cognoissance des traicts Geometriques, qui entendoit bien la vis sainct Gilles.

The workers call this sort of climbing vault the Saint-Gilles spiral staircase; for all that, there is a similar one at the Saint-Gilles Priory in Languedoc. When I was young I saw that he who knew how to cut stone in the style of the aforementioned Saint-Gilles spiral staircase and understood it well, was highly esteemed among the workers. They usually said among themselves that he understood geometry very well, he who know about the Saint-Gilles spiral staircase. ${ }^{7}$

The mastery of stereotomy was one of the elements maintaining the supremacy of French architecture over Italian architecture, ancient or contemporary. Books 3 and 4 of Philibert's Premier tome, the first printed method for stonecutting, highlight this integral practice of his art particularly, from the squinches at the Hôtel Bullioud in Lyon (1536) [Fig. 9.5] to the Tuileries staircase in the 1560 s. Moreover, mastering this art had consequences for the decoration. Still referring to the Saint-Gilles spiral staircase, De l'Orme continued in his criticism of Bramante's Belvedere staircase, saying: 'if the architect who constructed it had understood geometrical stonecutting, which I am referring to, he would have slanted it all, I say even the bases and the capitals which he all made square, as if he had wanted to make them part of a portico, which is straight and level. 8 The architect, who remains nameless here, 'understood nothing of what an architect must know. For instead of making the vault out of bricks, he should have made it out of stone, and from one column to another, placed slanting arches'. ${ }^{9}$ Bramante understood nothing of the 'art of stonecutting', and that is a testimony of the inferiority of Italian architecture. Slanting bases and capitals are, in fact, a characteristic of French art, very widespread in the architecture of the fifteenth century (for example, in the spiral 'ramps' in the castle of Amboise) and the beginning of the sixteenth century, such as in

7 De l'Orme, Premier tome de l'architecture, fol. 123v.

8 De l'Orme, Premier tome de l'architecture, fol. 124v: 'Mais si l'architecte qui l'a conduite euct entendu les traicts de géométrie, desquels je parle, il eust faict tout ramper, je dis jusques aux bases et chapiteaux, qu'il a faict tous carrés, comme s'il les eust voulu faire servir à un portique qui est droit et à niveau'.

9 De l'Orme, Premier tome de l'architecture, fol. 124v: 'Laquelle chose montre que l'ouvrier qui l'a faicte n'entendait ce qu'il faut que l'architecte entende. Car au lieu qu'il a faict la voûte de brique, il l'eust faicte de pierre de taille, et d'une colonne à autre des arcs rampants'. 


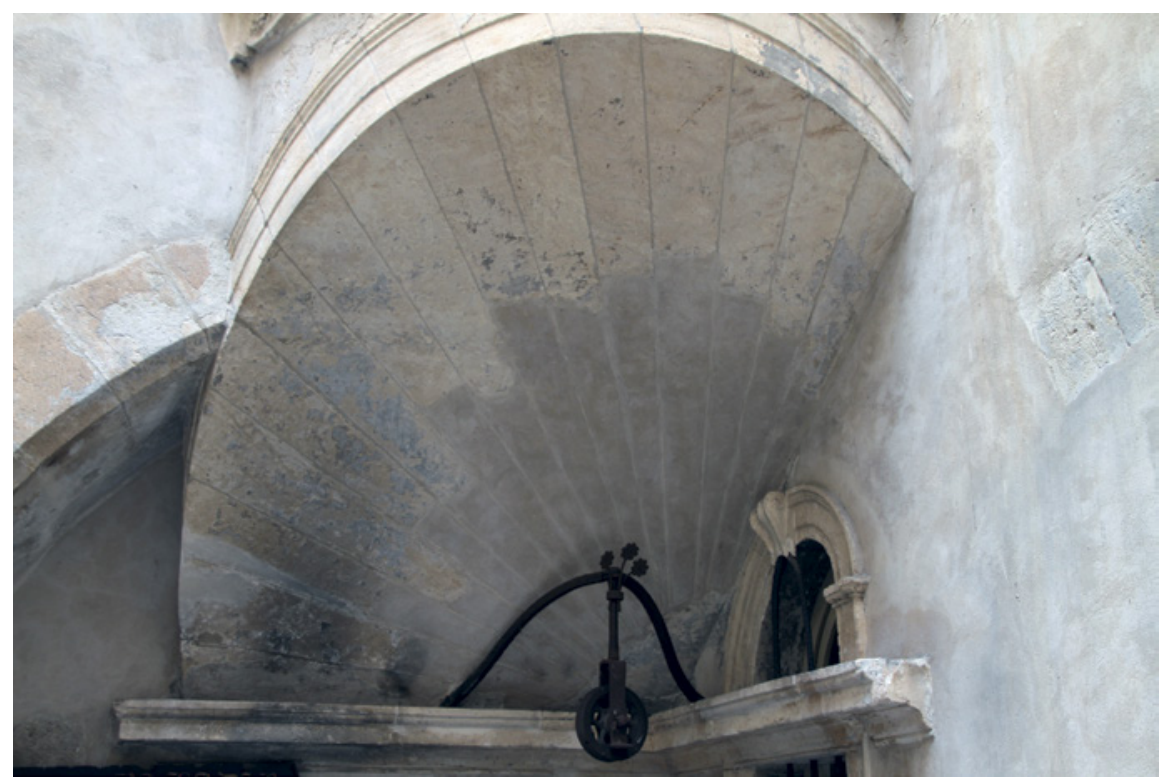

FIGURE 9.5 Philibert De l'Orme, Hôtel Bullioud, Lyon (1536) IMAGE (C) Y. PAUWELS

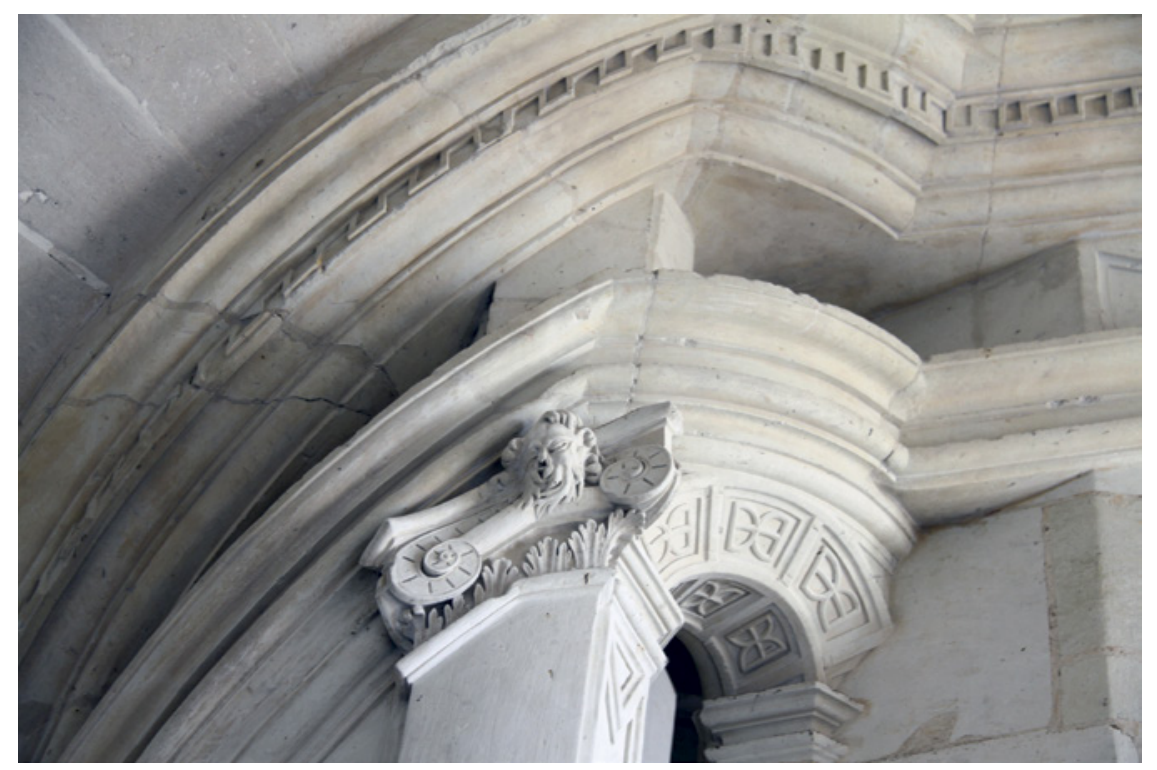

FIGURE 9.6 Capital of the staircase of château Oiron (ca. 1540)

IMAGE (C) Y. PAUWELS 
the castles of Oiron [Fig. 9.6], Chambord, and Châteaubriant, but also during the seventeenth century, in practice (great château and private residence staircases) as in theory, as in the works of Abraham Bosse ${ }^{10}$ and Father Derand. ${ }^{11}$

In other respects, the techniques of Gothic art were still very much alive. In fact, De l'Orme knew how to assemble a rib vault. He recalled in his Instruction, ${ }^{12}$ a text he wrote in his defence after Henry II died, that he had proved it in the Vincennes chapel. Moreover, the Premier tome is very clear on the subject:

Les maistres maçons de ce royaume, et aussi d'autres pays, ont accoustume de faire les voutes des églises esquelles y a grand espace (comme sont grandes salles) avec une croisée qu'ils appellent croisée d'ogives [...] Ces façons de voûtes ont esté trouvées fort belles, et s'en voit de bien exécutées et mises en œuvre en divers lieux de ce royaume, et signamment en ceste ville de Paris, comme aussi en plusieurs autres. Aujourd'huy ceux qui ont quelque cognoissance de la vraye architecture, ne suivent plus ceste façon de voute, appelée entre les ouvriers La mode Françoise, laquelle véritablement je ne veux dépriser, ains plustost confesser qu'on y a faict et pratiqué de fort bons traitcs et difficiles.

The master masons of this kingdom, and also of other countries, are accustomed to making the vaults of the churches [in which] there is a large space (since they are large halls) with a crossing they call a ribbed vault. $[\ldots]$ These sorts of vaults were considered very beautiful, and one can see them well carried out and implemented in many places of the kingdom, and especially in this city of Paris as also in several others. Today those who have some knowledge of true architecture no longer follow this fashion of vaulting that the workers call the French style, which I truly do not want to underestimate, but I would rather confess that very good and difficult work has been done and achieved there. ${ }^{13}$

Here Philibert is commenting on the pattern of a typical flamboyant Gothic vault, with girts and tiercerons, exactly the same as what was still being built at the turn of the sixteenth century - for example, the porch of Saint-Germain

\footnotetext{
10 Bosse Abraham, Traité des manières de dessiner les ordres (Paris, Abraham Bosse: 1664).

11 Derand François, Architecture des voûtes, ou l'art des traits, et coupe des voûtes (Paris, Sébastien Cramoisy: 1643).

12 Instruction de Monsieur d'Ivry, dit De l'Orme, abbé de Saint-Serge, et cestui Me architecteur $d u$ Roi: 'the chapel of Vincennes, where I had all the arches made and completed'. Quoted in Blunt A., Philibert De l'Orme (London: 1958) 151.

De l'Orme, Premier tome de l'architecture, fol. 107r.
} 
l'Auxerrois. In the middle of book 4 , this text is placed between the chapters devoted to squinches - particularly the one at Anet, the architect's great masterpiece - and those in which he explains the technique of 'spherical' vaults (domes and quarter-spheres), before he concludes with spiral staircases. Thus, 'modern' vaults are recognized in the Premier tome; De l'Orme proposes two other examples of them. The first one is more complex. As for the second, it was taken from the Nouvelles inventions (1561), where the ribs were created out of wood; here, they can be carved in stone.

In Philibert's mind, the durability of the Gothic technique could remain compatible with more modern structures, like the dome. Admittedly, this new form of vaulting (with which, De l'Orme seems to forget, Romanesque medieval builders were still acquainted) offered many advantages:

Les voutes desquelles je veux icy parler sont trop plus fortes et meilleures que celles qu'on avoit accoustumé de faire par ci-devant, et de beaucoup plus grande industrie, et plus longue durée, (pourveu qu'on les sçache bien conduire et mettre en œuvre) comme aussi de beaucoup moindre dépense, pour n'y appliquer des arcs-boutants.

The vaults I wish to talk about here are much stronger and better than the ones that used to be built, and more imaginative and longer-lasting (provided one knows how to build them correctly) and less expensive, for not building flying buttresses there. ${ }^{14}$

Nonetheless, De l'Orme planned to decorate these vaults by keeping the ribs of the modern repertoire; he gives a rather unexpected example of this:

Vous pouvez encores faire par dessous le pendentif de mesmes sortes de branches, que lon a faict en la voute de la mode Françoise, soit en façon d'ogives, liernes, tiercerons, ou autres, voire avec des clefs surpendues, et de plus grande grace que lon n'a point encores veu. Ceux qui voudront prendre la peine, cognoistront ce que je dy par la voute spherique laquelle j'ay faict faire en la chappelle du chasteau d'Annet, avec plusieurs sortes de branches rempantes au contraire l'une de l'autre, et faisant par mesme moyen leurs compartiments qui sont à plomb et perpendicule dessus le plan et pavé de ladite chapelle, qui fait et monstre une mesme façon et semblable à celle que je propose par la figure subsequente. 


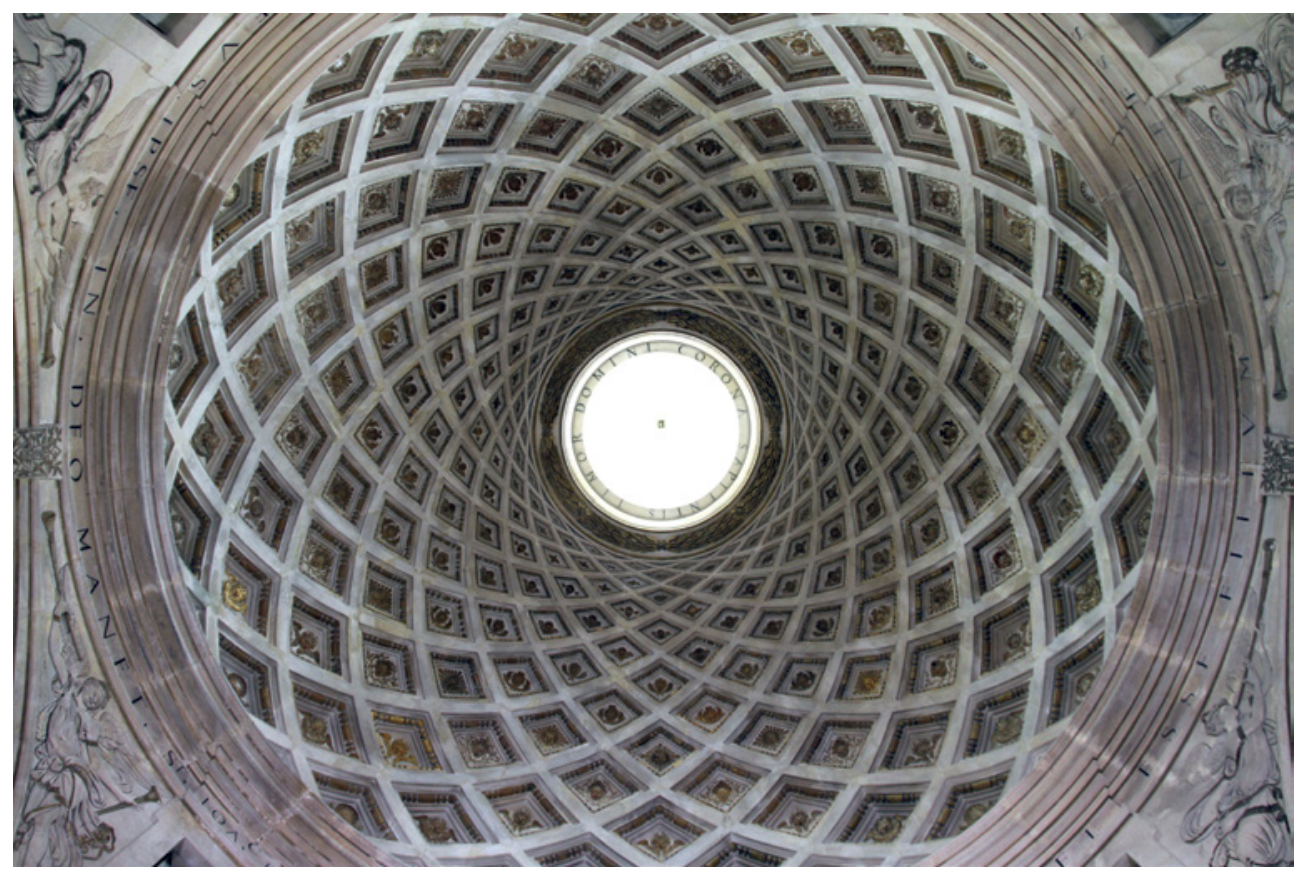

FIGURE 9.7 Philibert De l'Orme, Dome of the chapel of château d'Anet (1553) IMAGE (C) Y. PAUWELS

Underneath the pendentive you can still make the same sort of ribs, which were part of the vault in the French style, either in the form of ribs, ridge ribs, tiercerons, and so on, or even with hanging keystones, and more graceful than have yet been seen. Those who wish to make the effort will know what I am talking about in the hemispherical vault which I had constructed in the chapel of the château d'Anet, with several sorts of ribs climbing against each other, and making in this same way their compartments which are at right angles and perpendicular above the plan and the paving of the aforementioned chapel, which shows which shows a similarity to that which I propose in the following diagram. ${ }^{15}$

The sensational design of the dome of the chapel at Anet [Fig. 9.7] would therefore, in the spirit of its creator, be more of an avatar of the Gothic ornamental system than a throwback to the semi-domes in the Temple of Venus and Roma in Rome, which Anthony Blunt quoted as a precedent. ${ }^{16}$

15 De l'Orme, Premier tome de l'architecture, fol. 112r.

16 Blunt, Philibert De l'Orme 42. 


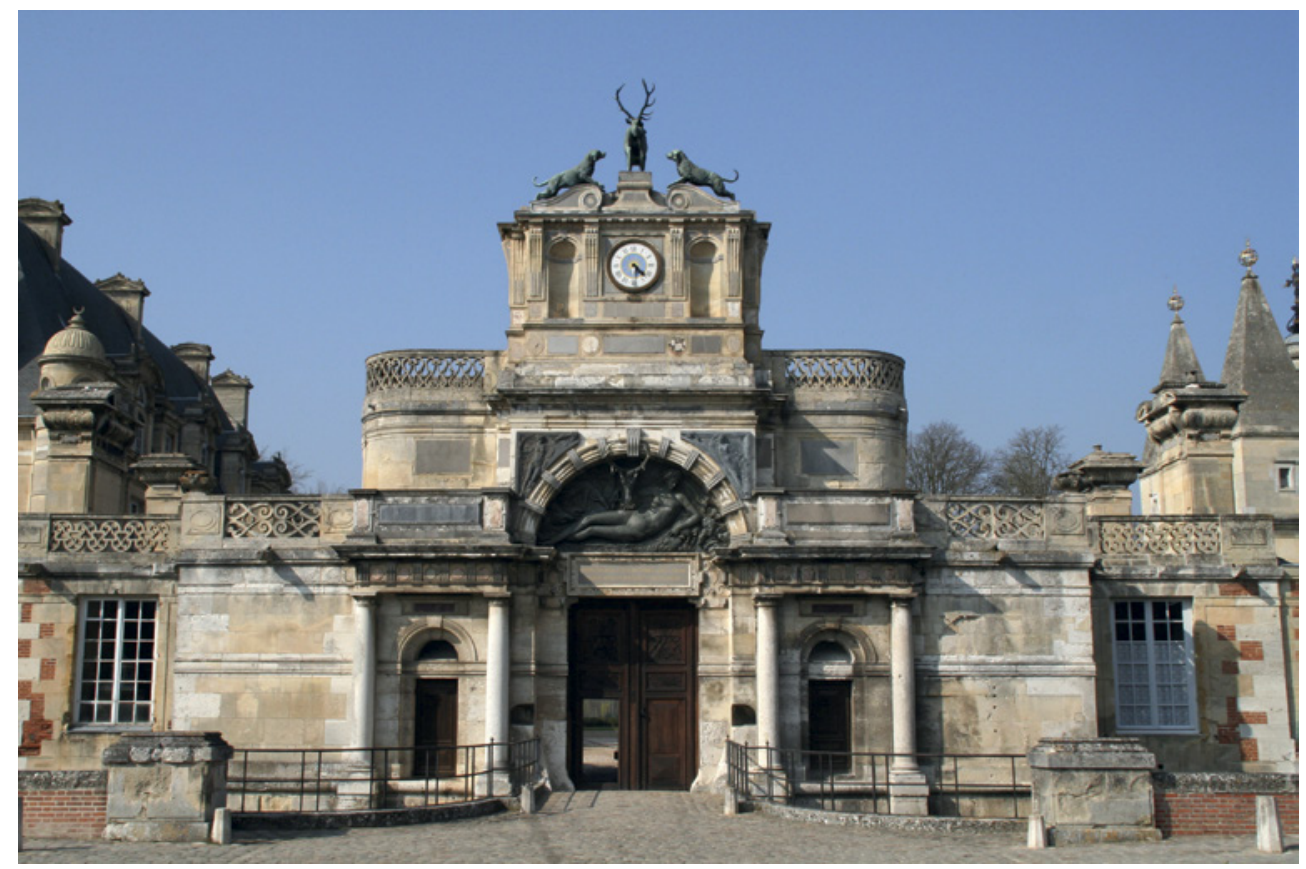

FIGURE 9.8 Philibert De l'Orme, Entrance of château d'Anet (1553)

IMAGE (C) Y. PAUWELS

\section{Elevations and Ornamentation: The Medieval Spirit}

Medieval art influenced Philibert in other areas. When he returned from Rome in 1536, he initially devised the modernization of banker Antoine Bullioud's Lyon residence with sophisticated architectural orders and baskethandle arches, typically flamboyant, a form frequently used during the first Renaissance, for example at Gaillon and Oiron. But as his career advanced, more subtle treatments allowed De l'Orme to achieve a more accomplished synthesis. At the château d'Anet, the originality of the castle entrance (built in the 1550s) is striking [Fig. 9.8]. If the reference to a triumphal arch is evident in the rhythm of the four Doric columns, the relationship of the arch to the order is in no way ancient; placed above the entablature, the tympanum is framed in a very original way which recalls the great Italian parietal tombs and this refers to the funerary symbolism of the château, which is also a mausoleum. But it is also very similar to that of many Romanesque façades, like that of Saint-Gilles-du-Gard [Fig. 9.9], with which De l'Orme was acquainted, and, not far from there, that of the cathedral of Saint-Trophime in Arles. 


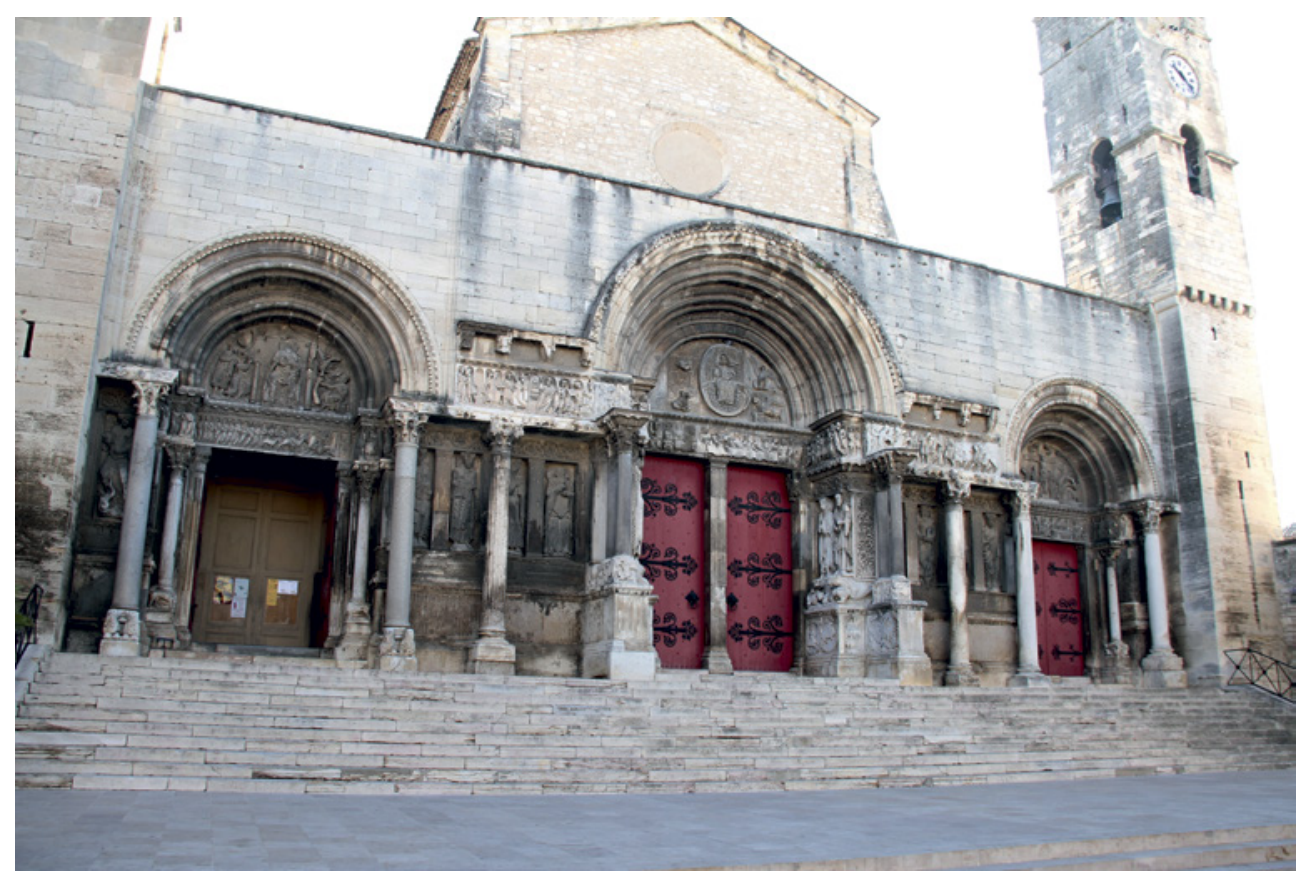

FIGURE 9.9 Abbey church Saint-Gilles at Saint-Gilles-du-Gard (1120-116o) IMAGE (C) Y. PAUWELS

Moreover, in his work one can find other examples of classical forms encased in obviously Gothic elements, or at least in the Gothic spirit. The balustrades on the castle entrance at Anet are definitely not Italian in style; they have subtle interlacing, closer to medieval forms than to Italian balustrades. The ribs in the vault are in the same spirit, and the criss-crossing of their contours truly corresponds to the taste for complicated lines, which greatly enthused the artists of the flamboyant Middle Ages. Anthony Blunt has already pointed out the process regarding the Ionic capitals of the tomb of François I in Saint-Denis:

Moreover, De l'Orme not only accepts the intersection of two volutes, but emphasizes it by making the edge of each volute cut across the other and penetrate into the cushion of the capital, with an effect which recalls the intersecting mouldings of Flamboyant architecture, rather than anything to be found in classical architecture. ${ }^{17}$ 
Last example, the entrance of the main wing at Anet which is reassembled today at the École nationale supérieure des Beaux-Arts in Paris. The lower third parts of its columns, in the Corinthian order, are carved very realistically, with laurel branches, their leaves, and fruits. The effect is emphasized because the branches pass under the band separating the lower part of the column from the rest, usually fluted, and come to an end naturally in the fluting of the upper part. This naturalism is in and of itself unknown to Italian practices, which leaned more towards more stylized and abstract shapes. The carved plant accentuates the naturalism even more, in a spirit more Gothic than classic.

\section{Christian Antiquity}

At the same time, Anet's Corinthian columns bring another precedent to mind, because the alternating fluted parts and parts carved with plant motifs and the slanting movement of the laurel branches are an obvious reference to the twisted columns or colonne vitinee of the choir in the old St Peter's. De l'Orme saw them in Rome when he was young. ${ }^{18}$ Here, we are taking up a source which is also part of our architect's originality: early Christian architecture, which Philibert mentions among the antique examples. He was the only one in France at that time to evoke it so precisely, writing several times in the Premier tome of his interest in old Roman churches. He visited Santa Sabina, where he noticed a fine door:

J'ay bien trouvé aussi une autre sorte de mesure en une porte antique, fort belle, et sans grand ornement, étant en l'eglise de saincte Sabine à Rome, laquelle a de largeur pour son ouverture par le bas, treize palmes [...], l'architrave, ou moulure qui est au pied droict par le devant, sur la premiere marche, a de largeur deux palmes, onces trois, et au plus hault au droit de la couverture de la porte, palmes deux, minutes quatre, qui sont trois minutes et une once de largeur plus que par le dessous.

I also found another sort of measurement in an ancient door, very beautiful, and without much ornamentation, in the Santa Sabina church in Rome, which has an opening whose lower width is thirteen palms high

18 Androuet du Cerceau also mentions these columns in the XXV exempla arcuum (Orléans, s.n.: 1549), and so does Serlio in the Livre extraordinaire - Extraordinario Libro (Lyon, Jean de Tournes: 1551). See Pauwels Y., L'architecture et le livre en France à la Renaissance: 'une magnifique decadence?? (Paris: 2013) 229-238. 
[...]. The architrave, or moulding which is on the jamb at the front, on the first step, is two palms, three inches wide, and at the highest point perpendicular to the door covering, two palms, four minutes, which is three minutes and one inch wider than the bottom. ${ }^{19}$

At Santa Prassede, a column, as commendable as those at the Pantheon or the ruins at the Forum, attracted his attention:

Doncques j'en proposeray encore une qui m’a semblé fort belle, et est à Sainte-Praxède à Rome, n'ayant que seize palmes, minute une, et onces trois pour sa hauteur: et pour son diamètre d'en bas, palme une, minutes dix, et once une. [...] Je vous puis bien asseurer, que c'est une des belles colomnes et aussi plaisante qu'il s'en voit point à Rome.

Thus I will propose another one which seemed very beautiful to me, at Santa Prassede in Rome, only sixteen palms, one minute, three inches high; and for its lower diameter, one palm, ten minutes and one inch [...]. I can assure you that it is one of the most beautiful and appealing columns ever seen in Rome. ${ }^{20}$

Santa Maria in Trastevere, another edifice he studied carefully, gave him a fine example of an Ionic capital:

Vous avisant que je ne me veux ayder en cecy totalement dudit Vitruve, ains seulement en partie, l'accompagnant de ce que j'ai trouvé aux chapiteaux antiques, et mesme à ceux de l'eglise de nostre Dame de Transtebre qui est aux faulxbourgs de Rome du coste de sainct Pierre de Montorio dela le Tybre. C'est une église bastie de plusieurs sortes de colomnes accompagnées de chapiteaux Ioniques fort différents les uns des autres, et ramassez de plusieurs edifices et ruines des antiquitez pour edifier ladicte eglise.

Informing you that I do not want to be helped totally in this by the aforementioned Vitruvius, only in part, accompanying it with what I have found in the ancient capitals, and even in those of Santa Maria in Trastevere on the outskirts of Rome, near San Pietro in Montorio beyond

19 De l'Orme, Premier tome de l'architecture, fol. 237 r.

20 De l'Orme, Premier tome de l'architecture, fols. 190v-191r. 
the Tiber. The church is built of several sorts of columns with Ionic capitals that are very different from each other, collected from several ancient buildings and ruins to construct the aforementioned church. ${ }^{21}$

In his own constructions, De l'Orme's interest in early Christian architecture is less apparent than his interest in the Gothic. Nevertheless, it is possible to find a few traces of it in his most original creations. Thus, the capitals of the interior order of the chapel at Anet, avoiding the Vitruvian canon, have no 'classic' precedent in the ruins of ancient Rome [Fig. 9.10]. On the other hand, one can see a recollection of the capitals of Santa Pudenziana, two steps away from Santa Prassede, the latter being mentioned explicitly by De l'Orme [Fig. 9.11]. In both cases, a basket carries long, narrow leaves; a rather simple abacus crowns it all. The capital at Anet is more elaborate, with additional motifs, such as the poppy fruit, here reinforcing the funerary symbolism of the chapel. However, the Roman precedent could have provided him with the original idea.

Again, it was Anthony Blunt who made the connection between the 'French' columns created by De l'Orme for the Tuileries and the columns in the choir at Santa Prassede. ${ }^{22}$ The superimposed drums and the crowns of foliage giving rhythm to the elevation of the shaft are in fact very similar; there is also a resemblance between the columns in the chapel in the garden of the castle of Villers-Cotterêts, where Philibert had implemented that system for the first time. But, at least for the plant crowns, the precedent of the twisted columns of St Peter's is essential, since they were also endowed with a similar decoration at their base. Apart from the French nature that De l'Orme linked to these columns - because the use of drums is appropriate for the natural qualities of French stones - the Santa Prassede motif was quite successful in the architecture of the kingdom. It can be found in a plate dated 1566, added by Jean Bullant to his Reigle d'architecture, ${ }^{23}$ which probably inspired Hugues Sambin in making the wooden columns of the chapel enclosure in the Palais de Justice in Dijon. ${ }^{24}$ But in Philibert's case, the most interesting aspect is precisely that the banded columns were of a 'French' nature while simultaneously being 'modern'. He speaks of them just as if they were Gothic vaults; both of them are 'modern' and 'French'. Gothic vaults, or 'voûtes modernes', are 'voûtes

\footnotetext{
21 De l'Orme, Premier tome de l'architecture, fol. 162r.

22 Blunt, Philibert De l'Orme, fols. 120-121.

23 Pauwels Y., "Jean Bullant et le langage des ordres: les audaces d'un timide", Gazette des Beaux-Arts 129 (1997) 85-100.

24 Pauwels Y., "La fortune de la Reigle de Jean Bullant aux XVI e et XVII e siècles", Journal de la Renaissance 3 (2005) 111-119.
} 


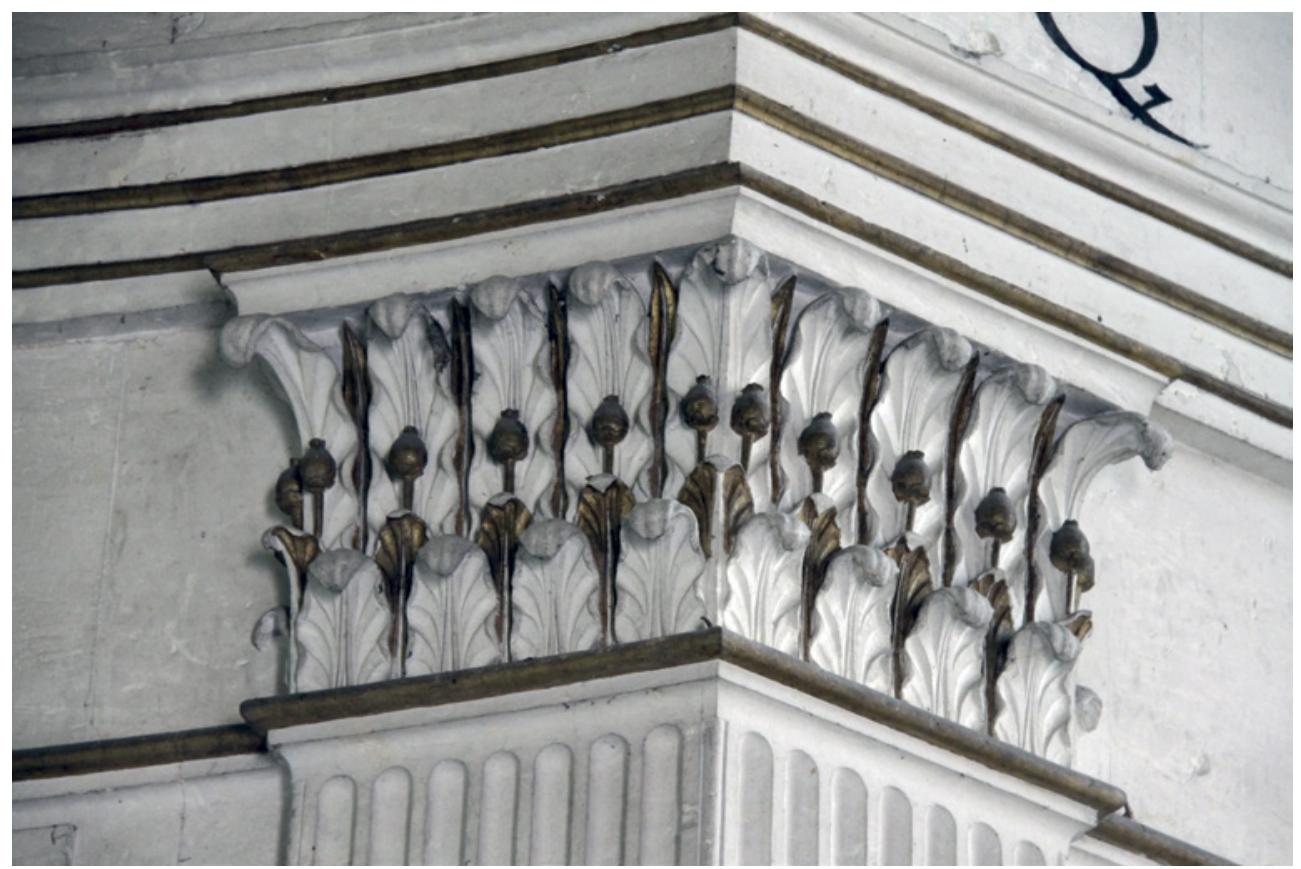

FIGURE 9.10 Philibert De l'Orme, Capital of the chapel of château d'Anet (1553) IMAGE (C) Y. PAUWELS

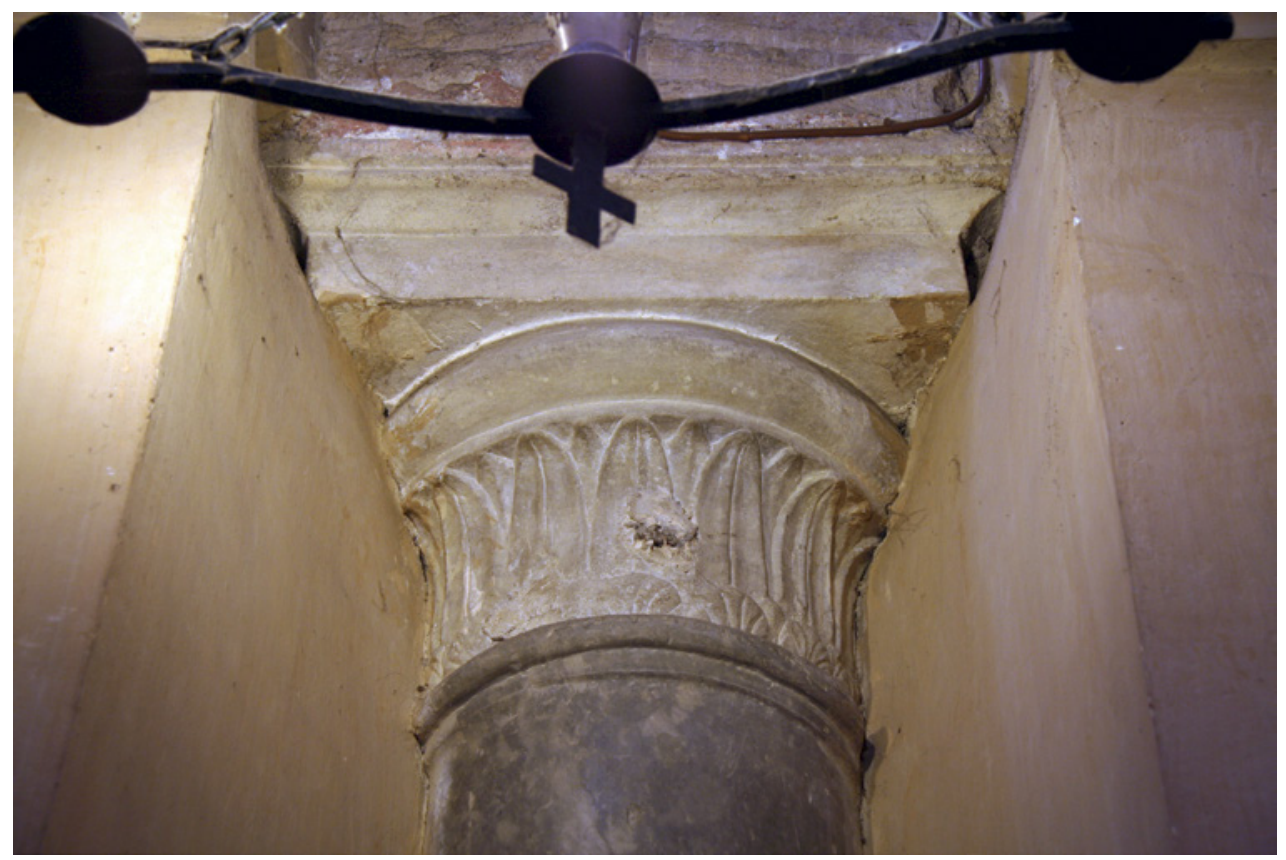

FIGURE 9.11 Capital of the nave of S. Pudenziana, Rome (end of the fourth century) IMAGE (C) Y. PAUWELS 
de la mode et façon française' (vaults in the French style and manner), ${ }^{25}$ and French columns 'modernes que nous appelons françaises' (modern, which we call French). ${ }^{26}$

All of this puts us at the heart of the problem of national identity, one element of which consists in the search for historical roots. The France of Francis I and Henry II was considered the ultimate stage of the translatio studiorum. In the same way the Dorians invented the Doric order, Ionians the Ionic order, and people of Corinth the Corinthian order - and, later, Romans the Composite or Italic order, to show their domination over the Greek world Frenchmen, as heirs of the Roman political and cultural leadership, had to imagine a specific order. The enumeration of the orders of the columns, from the Tuscan to the French order, emphasizes very well that the series of the orders is parallel to the succession of empires. The French order was a culmination, and as such, a synthesis of previous architectures. Its early Christian reference is clearly the noblest one, for in the setting of a Christian kingdom, it establishes the tradition in a 'moralized' antiquity, rid of its pagan residues. But nevertheless, it was not incompatible with the Gothic reference. The 'modern French' column was in fact linked to 'modern French' architecture by its very structure. Unlike the monolithic marble ancient (or Italian) column, it is made up of superimposed drums, for the very nature of the stone quarried from the soil of the kingdom calls for such an arrangement. In fact, it was the very structure of the Gothic piers that De l'Orme adapted to the ancient repertoire: the act of superposing elements underlies the construction of the supports and arches in the great Gothic buildings.

From this point of view, whereas Jean Bullant and Pierre Lescot remained more sensible and more strictly 'classical', De l'Orme agreed with Androuet du Cerceau in admiring and using methods of Gothic ornamentation. But he went further, for his direct knowledge of Rome allowed him to assimilate early Christian monuments into his cultural frame of reference in a way that Du Cerceau, in spite of his universal curiosity, could only know indirectly. It is in such a way that Philibert's modern order must be interpreted as a synthesis of classical antiquity (it kept a Doric, Ionic, or Corinthian capital), of Christian antiquity, and of the medieval opus francigenum. In order to create a specific French architecture, in the same way the poets of the Pléiade intended to write, in French, a national poetry for the glory of the Valois dynasty, De l'Orme looked for a synthetic language which included many sources: Roman antiquity, because the king of France was the new Augustus; Christian

25 De l'Orme, Premier tome de l'architecture, fol. nov.

26 De l'Orme, Premier tome de l'architecture, fol. 222 . 
antiquity, because as Roi très chrétien, the very Christian king, he was also the new Constantine; ${ }^{27}$ and medieval roots, because they were familiar to the French conception of building, which stayed close to the Sainte-Chapelle of Saint Louis. In some ways, this approach contrasts with that of the Spanish king. The palace of Charles V in Granada, built by Pedro Machuca in the 1530 , is indeed a fundamentally Italian building, inspired by works of Bramante and the ideas of Giulio Romano; as such, it is a symbol of the king's loyalty to Roman Catholicism. It was not the case in the Gallican France, where the quest for cultural roots seems very specific in all of the fields of artistic and poetic creation.

\section{Bibliography}

\section{Manuscript}

De l'Orme Philibert, Instruction de Monsieur d'IVry, dit De l'Orme, abbéde Saint-Serge, et cestui Me architecteur du Roi, Paris, Bibliothèque nationale de France, MS. Moreau 801 (XXXv A, 30-72) fols. 204-206.

\section{Books Published before 1800}

Androuet du Cerceau Jacques, XXV exempla arcuum (Orléans, s.n.: 1549).

Androuet du Cerceau Jacques, Second Livre d'architecture (Paris, André Wechel: 1561).

Bosse Abraham, Traité des manières de dessiner les ordres (Paris, Abraham Bosse: 1664). De l'Orme Philibert, Les nouvelles inventions pour bien bastir (Paris, Federic Morel: 1561). De l'Orme Philibert, Le premier tome de l'architecture (Paris, Federic Morel: 1567).

Derand François, Architecture des voûtes, ou l'art des traits, et coupe des voûtes (Paris, Sébastien Cramoisy: 1643).

Du Bellay Joachim, Deffence et illustration de la langue francoyse (Paris, Arnoul L'Angelier: 1549).

Pasquier Étienne, Les recherches de la France d'Estienne Pasquier conseiller et avocat général du Roy (Paris, Laurent Sonnius: 1621).

Serlio Sebastiano, Livre extraordinaire - Extraordinario Libro (Lyon, Jean de Tournes: $1551)$.

27 References to the Forum of Augustus, to the Temple of Mars Ultor and to the Lateran Baptistery, where Constantine would have been baptized, appear clearly in the Salle des Caryatides in the Louvre, where the king's throne was. See Pauwels Y, "Athènes, Rome, Paris: la tribune et l'ordre de la Salle des Caryatides au Louvre", Revue de l'Art 169 (2010) 61-69. 


\section{Scholarly Literature}

Blunt A., Philibert De l'Orme (London: 1958).

Huppert G., "Naissance de l'histoire en France: les 'Recherches' d'Estienne Pasquier", Annales. Economie, Sociétés, Civilisations 1 (1968) 69-105.

Pauwels Y., L'architecture et le livre en France à la Renaissance: 'une magnifique decadence?'(Paris: 2013).

Pauwels Y, "Athènes, Rome, Paris: la tribune et l'ordre de la Salle des Caryatides au Louvre", Revue de l'Art 169 (2010) 61-69.

Pauwels Y., "La fortune de la Reigle de Jean Bullant aux XVI e et XVII e siècles", Journal de la Renaissance 3 (2005) 111-119.

Pauwels Y., "Jean Bullant et le langage des ordres: les audaces d'un timide", Gazette des Beaux-Arts 129 (1997) 85-100.

Pauwels Y., "Petits arrangements avec le réel. Jacques Androuet du Cerceau à Écouen", Revue de l'Art 178 (2012) 33-41. 